\title{
NOTICE OF BOOK
}

Life and Letters of Sir Joseph Dalton Hooker, O.M., G.C.S.I. By LEONARD Huxley. London: John Murray.

THE appearance of 'The Life and Letters of Sir Joseph Dalton Hooker', by Mr. Leonard Huxley, is an event which concerns the botanical world so nearly as to warrant a deviation from the policy, now for many years adopted by this Journal, of excluding notices of current literature from its pages. An even more intimate reason for exceptional procedure on the present occasion lies in the fact, perhaps not generally known, that Sir Joseph Hooker was one of those who contributed greatly to the right starting of the 'Annals of Botany'.'

The life of Hooker is largely bound up with the great advance of biological science during the latter half of the last century, and his own scientific eminence, as well as his official position at Kew during a very critical period, invests with peculiar interest the full account of his life which is set forth in Mr. Huxley's two volumes. Vivid pictures are drawn of the contests waged in those early days with official stupidity and meanness, and of efforts, often made in vain, to convince those responsible for guiding the destinies of this country, its Imperial and Colonial expansion no less than the development of its resources at home, of the importance of botany as a serious factor in material progress. The story of the yet more fundamental and world-wide struggle, culminating in new measures of intellectual freedom, as well as in that wider outlook on life which was opened up by the new conception of the origin of species, has more than once been told. For the philosophical historian the correspondence between Hooker and Darwin, which forms no inconsiderable part of the Letters, must always possess a special value and significance. Some of the familiar incidents in the great evolution campaign acquire new meaning, and others are here unfolded for the first time. Hooker's great wealth of knowledge served continually to reinforce the position of tenacious criticism which he ever maintained towards unproved inferences and unsubstantiated hypotheses. It also provided a powerful instrument in forging the new weapons with which Darwin was to shatter the old dogmas concerning the constancy of species, and thence to bring about the greatest philosophical upheaval the modern world has ever known.

This, however, is not the place to attempt to analyse Hooker's contributions to the edifice of Science, however important they are, or indeed to dwell upon them in any detail. Others have already discussed these things in many journals and reviews. But it is the place to indicate emphatically that the 'Life and Letters' is a book that deserves to be read by all botanists, and especially perhaps by the younger generation. Hooker's was no life of ease. It is the story of strenuous effort and continuous

1 The writer is indebted to Professor I." Bayley Balfour, to whose energy and foresight the original idea and ultimate realization of the Annals of Botany was mainly due, for access to Hooker's letters during the pre-natal period of its development.

[Annals of Botany, Vo1. XXXIV. No. CXXXIII. January, 1920.] 
work crowned by great achievement. Mr. Huxley has treated his subject with admirable tact. It is Hooker himself, through his letters, who is telling the story of his life. And in this self-revelation we seem to gain an intimate knowledge of the man himself, ever modest-almost to a fault-and endowed with a nobility of character which would have ensured for him an honoured position, whatever the walk of life he might have marked out for his own.

It is impossible to read the 'Letters' without being struck by the wisdom, founded as it was on natural shrewdness and accumulated experience, which made Hooker's advice and criticism so valuable to his friends and colleagues. He was not always easy to convince at the outset, and this quality of caution, which had served him in good stead both in scientific and official matters, again found expression when the inception of the 'Annals of Botany' was under discussion. But no sooner had he assured himself that the enterprise deserved his support than he rendered it with his whole heart. It is safe to say that some day, when the early history of this Journal comes to be written, the share taken by Hooker in launching the new enterprise on the botanical world will be seen to have been no small one. 


\section{$2 \mathrm{BHL}$ Biodiversity Heritage Library}

1920. "Life and Letters of Sir Joseph Dalton Hooker, by Leonard Huxley

[Review]." Annals of botany 34, 140-141.

https://doi.org/10.1093/aob/os-34.1.140.

View This Item Online: https://www.biodiversitylibrary.org/item/236972

DOI: https://doi.org/10.1093/aob/os-34.1.140

Permalink: https://www.biodiversitylibrary.org/partpdf/320282

\section{Holding Institution}

Smithsonian Libraries

\section{Sponsored by}

Biodiversity Heritage Library

\section{Copyright \& Reuse}

Copyright Status: Not in copyright. The BHL knows of no copyright restrictions on this item.

This document was created from content at the Biodiversity Heritage Library, the world's largest open access digital library for biodiversity literature and archives. Visit BHL at https://www.biodiversitylibrary.org. 